\title{
GEOMATICS EDUCATION: NEED ASSESSMENT
}

\author{
Anjana Vyas ${ }^{1}$ \\ ${ }^{1}$ Professor and Acting Dean, Faculty of Technology, CEPT University, Ahmedabad, Gujarat, India, anjanavyas@cept.ac.in
}

\section{Commission VIII}

\begin{abstract}
:
Education system is divided in to two classes: formal and informal. Formal education establishes the basis of theory and practical learning whereas informal education is largely self-learning, learning from real world projects. Generally science and technology streams require formal method of education. The social and related aspects can be taught through the other methods. Education is a media through which the foundation of the knowledge and skill is built.
\end{abstract}

The statistics reveals the increase in the trend of the literate population. This may be accounted due to the level of urbanization and migration to the cities in search for the 'white-collar jobs'. As a result, a shift in the employment structure is observed from a primary sector to a secondary and tertiary sector.

Thomas Friedman in his book 'The World is Flat' quotes the impact of globalization on adaptation of science and technology, the world has become large to tiny. One of the technologies to mention here is geospatial technology. With the advancement in the satellite remote sensing, geographical information system, global positioning system, the database management system has become important subject areas. The countries are accounting hugh budget on the space technology, which includes education, training and research.

Today many developing countries do not have base maps, they are lacking in the systemic data and record keeping, which are essential for governance, decision making and other development purpose. There is no trained manpower available. There is no standard hardware and software identified. An imbalance is observed when the government is promoting the use of geospatial technology, there is no trained manpower nor the availability of the experts to review the accurateness of the spatial data developed. There are very few universities which impart the degree level education, there are very few trained faculty members who give standard education, there exists a lack of standard syllabus. On the other hand, the industry requires high skilled manpower, high experienced manpower. This is a low equilibrium situation.

Since the need is enhancing day by day, the shortage of the skilled manpower is increasing, the need of the geomatics education emerges. This paper researches on the need assessment of the education in geospatial specialization. It emphasises on the challenges and issues prevail in geospatial education and in the specialized fields of remote sensing and GIS. This paper analyse the need assessment through all the three actors: government, geospatial industry and education institutions.

\section{KEY WORDS:}

Education, Geospatial, Standardisation, Government, Need Assessment, Remote Sensing, Geographical Information System, Developing Countries, Syllabus

\section{INTRODUCTION}

Education as described in 'Wikipedia, The free Encyclopedia' is any act or experience that has a formative effect on the mind, character or physical ability of an individual. In its technical sense, education is the process by which society deliberately transmits its accumulated knowledge, skills and values from one generation to another. The education consists of the words bring up, bring out and bring forth what is within, identify the potential and to lead.
As defined by Merriam Webster, education is the knowledge and development resulting from an educational process. Education is an important process in human life which is a process of gaining knowledge and better living. It plays very important role in training and development of the human mind set to study and analyse the situation with application of technical and logical skill. Education is a formal system of teaching. It is hierarchically structured and chronologically graded education system. 


\section{ROLE OF GOVERNMENT}

Government is playing vital role in promoting application of geomatics in the policy making. The urban planning, environmental planning, industrialization, slum upgradation (mapping), land management are some of the areas where the geomatics has reached as baseline for decision making at national level. The available literature reveals that in India the geomatics is in its young age. The question for research is when the IT sector of the country is on the high ground, the space technology has made up the forefront in an international sphere then why not geomatics? Is geomatics is different than these? Why geomatics is treated as the bottom of all of above?

\section{MULTIDIMENSION APPROACH ON GEOMATICS EDUCATION}

There is an emergence need to adopt multidimensional approach to examine the reasons for primitive growth of geomatics in our country. The demand for geomatics-skilled manpower is observed increasing every day. The corporate sector is experiencing changes, in the early 1990s, most the GIS companies relied on outsourced business from overseas market with US, UK, Europe and other developed nations which is now changed to national level and local level projects. 'Education in geomatics' is one of the important factors play a very important role here in bridging the gap between the demand and the requirement of manpower. A good education has direct and positive relations with the quality of the human resources generated. A measurement of the marginal productivity becomes meaningful. The marginal productivity of skilled manpower earns the higher GDP for the nation.

The geomatics education offered by the universities is largely offer at post graduation level in India whereas it is offered from k-12 level to undergraduate and higher level in developed countries. A very important issue is to standardize the geomatics education worldwide. The technology is developing on fast rate, the implementation of the infrastructure and financial projects are at fast rate, the emergence need is to give a legal recognition so as the availability of human resources become boundary-less.

\section{BENEFITS OF EDUCATION}

Education is a productive investment in human resources resulting in personal growth and development improved social satisfaction, higher efficiency and better public services. Of course, education and training are indispensable components of any investment in new technology, Expenditure in public services, and such investments are prime catalysts in socio-economic development. GIS Education Targets the decision makers and planners, the managerial personnel, personnel carrying space technology tasks, technical support staff, research workers who develop interdisciplinary approaches and Teachers/ academia.

The Need for GIS has emerged as the real world has a lot of spatial data, manipulation, analysis and modeling can be effective and efficiently carried out with a GIS, the locality of the intended purchase of house, the transportation route for fire-fighting vehicles to the fire area, location of historical sites to visit, the earth surface for purposes of army. The demand of the resources is always higher than its availability. The earth surface has a limited resource, hence it requires rational decisions on space utilization along with fast and quality information in decision making. Again, management of these resources is complex due to the need to combine and process many sets of data, in addition to judge as many as possible situation that might happen. It has intense competition. On this scenario the need to use technology in making decisions and strategy in the world of intense competition. Applications of geomatics will improves/enhances the effects of physical/environmental growth and can generate multiple scenario in planning can be performed easily

\section{LIMITATIONS EXPERIENCED}

Limitations of the education in GIS, it requires hugh data and the data are costly. Secondly, learning curve of GIS can be long, it does not work in own environment but dependent to earth science and computer science. Time and cost factors play a major role in weakening the pace of the students enrolling in this discipline.

\section{FUTURE SCENARIO}

Of course, the users' scenario have developed over period of time. From digitisation to mapping to analysis, the requirement has increased to development and modelling. GIS Operators' position has shifted to GIS Engineer. From scientists to household level demand of GIS has developed. How to find the hotel or how to find the best education institute for admission of her son has become easier for mother to view through google and other popular sites. All on map, available in visualization mode. Many leading companies have invested large amount in the research and hence education and training has become the need of the day.

The future of GIS applications in education continues to grow rapidly. With the inclusion of remote sensing, desktop GIS, and Internet-based mapping, students are gaining the opportunities to become fully immersed in the analysis of spatial data. Many schools, grants, and companies are rapidly developing improved applications, with real data and the intention of solving known and unknown scientific problems. 


\section{SYNTHESIS}

The world has accepted the value of education in many specialised fields including earth and atmospheric sciences. The scenario of natural resources, climate, built environment, industrialization, infrastructure, disasters are changing continuously and affecting the human behavior. The changes are also taking place in the technology. The use of technology is very much important as much the technology development. It is therefore essential to have established training and education for the development of the appropriate technology as well as to learn how to use the technology. The second most important thing is expand the scope of education. There are several ways the education imparts. The most traditional manner is classroom environment. The other method is web-based, on-line class rooms.

The demand for the standard and professional education is increasing every day. This increase is due to the natural growth of the population, increase in the awareness regarding the usefulness of the education, enhancement of the job opportunities for the skilled and white collars, increase in the standard of living in the developing countries, etc. In order to cop-up the increasing demand the availability of the academic institutions and universities are not enough with respect to the specializations required. In the short time it is also not possible to raise the institutions capabilities. Simultaneously, the availability of the internet has increased with its performance since early 2000 . The computer literacy has reached to the door step of the poor as well as the rural community. An old man talking to his son through web-cam in any cyber café is a common scene observed at many places.

The access to metadata and GSDI has improved the opportunity of the web-based education. There are quite a few web-based education programmes known worldwide. Some of these are very successful. This paper looks into the issues and challenges in this method of education with specific emphasis on the streams of space science and geomatics. The standardization, the validation, the evaluation and review the content, quality, length, depth are some of the issues addressed here. The strategy for sustainability and longitivity of the programme also needs to be looked into. The education must be self financed or cross subsidized within the system.

\section{REFERENCES}

Katterfeld,C.; König, G., 2008. Analysis of E-learning Software and Guidelines for Quality Assurance in Photogrammetry, Remote Sensing and GIS. Int. Arch. Of Photogrammetry, Remote Sensing and Spatial Information Science, 36, part B6a, pp. 65-70. http://www. isprs.org/proceedings/XXXVII/congress/tc6a.aspx.

Pappas, C., 2013. Future eLearning Trends and Technologies in the Global eLearning Industry. http://elearningindustry.com/future-elearning-trends-andtechnologies-in-the-global-elearning-industry.

Shah, D., 2013. MOOCs in 2013: Breaking Down the Numbers. https://www.edsurge.com/n/2013-12-22-moocsin-2013breaking-down-the-numbers.

Wide Web Consortium, 2014. HTML5, A vocabulary and associated APIs for HTML and XHTML, W3C Candidate Recommendation $04 \quad$ February 2014, http://www.w3.org/TR/html5/. 